\title{
Migration and the education of children who stay behind in Moldova and Georgia
}

Citation for published version (APA):

Mazzucato, V., Cebotari, V., \& Siegel, M. (2016). Migration and the education of children who stay behind in Moldova and Georgia. International Journal of Educational Development, 51, 96-107.

https://doi.org/10.1016/j.ijedudev.2016.09.002

Document status and date:

Published: 01/11/2016

DOI:

10.1016/j.ijedudev.2016.09.002

Document Version:

Publisher's PDF, also known as Version of record

Document license:

Taverne

Please check the document version of this publication:

- A submitted manuscript is the version of the article upon submission and before peer-review. There can be important differences between the submitted version and the official published version of record.

People interested in the research are advised to contact the author for the final version of the publication, or visit the DOI to the publisher's website.

- The final author version and the galley proof are versions of the publication after peer review.

- The final published version features the final layout of the paper including the volume, issue and page numbers.

Link to publication

\footnotetext{
General rights rights.

- You may freely distribute the URL identifying the publication in the public portal. please follow below link for the End User Agreement:

www.umlib.nl/taverne-license

Take down policy

If you believe that this document breaches copyright please contact us at:

repository@maastrichtuniversity.nl

providing details and we will investigate your claim.
}

Copyright and moral rights for the publications made accessible in the public portal are retained by the authors and/or other copyright owners and it is a condition of accessing publications that users recognise and abide by the legal requirements associated with these

- Users may download and print one copy of any publication from the public portal for the purpose of private study or research.

- You may not further distribute the material or use it for any profit-making activity or commercial gain

If the publication is distributed under the terms of Article $25 \mathrm{fa}$ of the Dutch Copyright Act, indicated by the "Taverne" license above, 


\title{
Migration and the education of children who stay behind in Moldova and Georgia
}

\author{
Victor Cebotari $^{\mathrm{a}, *}$, Melissa Siegel $^{\mathrm{a}}$, Valentina Mazzucato ${ }^{\mathrm{b}}$ \\ a Maastricht Graduate School of Governance, Maastricht University, The Netherlands \\ ${ }^{\mathrm{b}}$ Department of Technology and Society Studies, Maastricht University, The Netherlands
}

\section{A R T I C L E I N F O}

\section{Article history:}

Received 10 February 2015

Received in revised form 2 September 2016

Accepted 5 September 2016

Available online 17 September 2016

\section{Keywords:}

Children left-behind

Migration

Transnational families

School performance

Moldova

Georgia

\begin{abstract}
A B S T R A C T
In Moldova and Georgia, two post-Soviet countries with high emigration rates, there is little systematic empirical research on the school performance of children whose family members migrate. This study uses nationally representative data (Moldova, $\mathrm{N}=814$; Georgia, $\mathrm{N}=655$ ) and employs child- and caregiver-reports of school performance of children living in different transnational family configurations. We found similar assessments of school performance by children and caregivers in Georgia, but results do suggest some differing perceptions in the Moldovan reports. Overall, fathers' migration, when mothers are caregivers, correspond to worsen education in Georgia. In Moldova, on the contrary, children with migrant fathers and cared for by mothers report improved school performance. Furthermore, in Moldova, better performance associates with parents being abroad, either together or divorced (child-reports) while decreased performance relates to the absence of remittances (caregiverreports). The findings highlight the importance of considering different transnational characteristics and who makes the assessment.
\end{abstract}

(c) 2016 Elsevier Ltd. All rights reserved.

\section{Introduction}

Moldova and Georgia are two countries with a significant share of their populations working abroad. According to World Bank (2011), approximately $25.1 \%$ of the Georgian and $21.5 \%$ of the Moldovan working-age adults have left the country by 2010. Many of these migrants lack the financial resources or legal conditions to take their children with them, thus, creating a network of transnational families. In the context of labor migration, it may actually be a preferred choice for migrants not to uproot their children when proper caregiving arrangements are available back home (Mazzucato et al., 2015). This strategy is often motivated by a desire to secure the well-being of children while living apart across borders. Studies show that parents engage in migration to provide better schooling and a higher standard of living for children and other family members who stay behind (McKenzie and Rapoport, 2011; Parreñas, 2005). Monetary and in-kind remittances have been found to increase the educational expenditure of the

\footnotetext{
${ }^{*}$ Corresponding author at: Maastricht Graduate School of Governance, Maastricht University, Boschstraat 24, 6211 AX, Maastricht, The Netherlands. E-mail address: victor.cebotari@maastrichtuniversity.nl (V. Cebotari).
}

household (Bredl, 2010), thus, creating an implicit assumption that children are the net beneficiaries of migration.

In reality, the educational outcomes of children depend not only on the economic effects of migration but also on a far more complex range of consequences surrounding the transnational care of children. Remittances may ease the financial burden of the household and provide material support for children's schooling. At the same time, the absence of family members may disrupt children's performance in school by leaving them without proper help, supervision and emotional support (Battistella and Conaco, 1998; Edwards and Ureta, 2003; Kandel and Kao, 2001). Therefore, migration constitutes a distinct form of separation because it simultaneously generates economic benefits and social costs for children who stay at origin (Dreby, 2010).

Indeed, previous research, mostly based on a single-country analysis, has found positive (Antman, 2012; Kandel and Kao, 2001), neutral (Cebotari and Mazzucato, 2016; Jordan and Graham, 2012; Robila, 2012), or negative (Cortes, 2015; Grigorian and Melkonyan, 2011; Hu, 2012; Kroeger and Anderson, 2014; Lu, 2014) associations between migration of family members and children's education. The opposing evidence in the literature is nuanced by the national contextualization of results and by the measurement of transnational conditions under which children's education benefits or suffers. A cross-country comparison in this respect is 
useful because it facilitates the development of generalized conclusions and helps to broadly interpret the effects of migration on children's education.

This study builds on existing gaps in the literature that were marginally targeted by previous research. Most studies primarily consider maternal and paternal absence and the effects of remittances on children's schooling. At the same time, important transnational characteristics, such as return migration, who is the caregiver when parents migrate, the separation that involves migration and marital discord, the use of remittances, are often neglected, leading to omission of important factors mediating the effects of migration in relation to children's education. Moreover, many studies fail to consider children in non-migrant families when examining the educational performance of children in transnational care. This omission makes it difficult to understand from an academic and policy perspectives if educational outcomes of children in migrant and non-migrant families differ from each other. Finally, most of the existing research focuses on Latin American and Asian countries. To our knowledge, this study is the first to explore and compare children in migrant and non-migrant families and their school performance in two former Soviet countries.

This study uses nationally representative, large-scale household data that were collected in 2011-2012 in Moldova and Georgia. The inclusion of these two countries was motivated by the need to compare contexts that share notable similarities in the region, such as the economic difficulties following a prolonged transition to democracy, the ongoing territorial disputes that threaten the consolidation of a strong state authority, and perhaps most importantly, the large and diversified out-migration flows that affect a significant number of families in both countries. The investigation focuses on school performance using subjective measures and two perspectives: (1) that of 11-18-year-old children and (2) the child's main caregiver who resides in the household. The goals of this study are twofold. The first objective is to reveal the effects of different transnational characteristics on children's educational performance. The second objective is to observe whether and how child- and caregiver-reports converge when measuring children's education. Comparing child and adult assessments is important because the existent studies often examine one perspective or the other and discrepancies between the two will provide insights about how best to measure children's education (Jordan and Graham, 2012). Five characteristics are offered to explain the complexity of transnational family arrangements. These characteristics include whether children live in nonmigrant, migrant or return-migrant households; whether parents migrate and are together or divorced; whether fathers, mothers or both migrate and children are cared for by a parent or grandparents; and whether migrants send remittances and whether remittances are prioritized for education. Understanding the complexity of transnational care arrangements is important for supporting policy actions for children living in evolving family forms such as the transnational family.

\section{Background}

\subsection{Migration and children's education}

Traditionally, the parent-child separation has been the focus of family studies that looked at extraordinary family circumstances such as parental divorce or death (Amato and Cheadle, 2005; Corak, 2001; McLanahan and Sandefur, 1994). This body of research draws upon child development and indicates that the main implication of child-parent separation and, therefore, the absence of parental input is that children are not living with one or both parents on a daily basis, which may inadvertently weaken children's cognitive development and education. However, not until recently has attention been given to analyzing separations because of migration in relation to children's education.

Indeed, at the turn of the century, transnational family studies have emerged to look specifically at families that span international borders. Within this stream of research, the education of children in transnational care has become a topic of scholarly interest (Antman, 2012; Cebotari and Mazzucato, 2016; Cortes, 2015; Dreby, 2010; Jordan and Graham, 2012; Nobles, 2011). These studies indicate a wide array of factors that may influence children's education, including specifics of family environment, who the migrant is, who the caregiver is, the stability of care, communication channels, and the availability of remittances for family and educational necessities. We argue that, conceptually, it is important to distinguish between different transnational household configurations to better understand the effects of living transnationally on children's education.

A recent but growing body of research considers the ways parents contribute to children's education from outside of the household. However, parental absence may take various forms through migration, divorce or both, among which the separation that involves both migration and divorce has been particularly scarcely analyzed. In one of the few studies that looked at marital status of migrant parents in relation to children's school performance, Cebotari and Mazzucato (2016) found no differing outcomes among Ghanaian, Nigerian and Angolan children whose parents migrated abroad and were divorced compared to children in non-migrant families. In Mexico, Nobles (2011) compared parental absence due to migration and parental absence due to marital dissolution and found that children with migrant fathers showed better educational outcomes compared with children separated from their parents because of divorce. However, in the same country, Creighton et al. (2009) found that both paternal absence because of migration and paternal absence due to divorce disadvantage children in schools. The difference in the outcome between migration, divorce or both is likely explained by the rationale of these forms of absence. For migrant parents, the wellbeing of children motivates the decision to migrate (Nobles, 2011). In the case of divorce however, the well-being of children is not always the decisive factor for migrating. For instance, Constable (2003) found that some Filipina wives see migration as an escape route from a problematic marriage. In general, migration may strain marital relationships, especially when women migrate alone or when both partners migrate at the same time (Caarls, 2015). When divorced parents migrate, they may lack the time and resources to invest in children, especially when they remarry and have children in that union (Dreby, 2010). While the dynamics of migration and marital dissolution are hard to detach from each other, these studies point to the need to place marital discord in the context of parental migration to better understand these processes in relation to children's education.

More often than not, migration is a strategy to improve the welfare of the household and of family members who stay behind (Edwards and Ureta, 2003). This view emphasizes the role of the family in the decision to migrate. Evidence shows that households with migrants are more likely to use remittances to pay for a variety of school costs, with positive effects on children's school enrollment, school attendance and school performance (Antman, 2012; Bennett et al., 2013; Edwards and Ureta, 2003). In Moldova and Georgia, however, previous research found that education is not a priority in household spending preferences, with money being primarily used for food, clothing, health or debts (Gerber and Torosyan, 2013; UNICEF, 2016). When remittances are spent on children's education, findings from other post-Soviet countries, such as Armenia and Kyrgyzstan, show limited improvements in children's school outcomes (Grigorian and Melkonyan, 2011; 
Kroeger and Anderson, 2014). It is likely that the willingness to invest in children comes with the perceived value of schooling in the origin and destination countries. Migrants who realize the benefits of education in the destination country are more likely to invest more in children's learning (Stark et al., 1997). On the contrary, migrants' perception of a low return from education may result in decisions to invest less in children (McKenzie and Rapoport, 2011).

Nevertheless, the effect of migration on children's education goes beyond the increased income from remittances. Distinguishing which migrant parent is absent is crucial for understanding the relationship between parental migration and children's performance in school (Cebotari and Mazzucato, 2016; Dreby, 2010). Although family practices vary across countries, motherhood and fatherhood are usually perceived differently regarding child rearing. In developing countries, mothers usually take the leading role in caring for children (Cortes, 2015). Therefore, maternal migration has been often found to incur substantial disruption in children's lives (Cortes, 2015; Parreñas, 2005). Fatherhood, by contrast, is associated more with authority and protection, which, in the case of paternal out-migration, may lead to the loss of the male role model and the disciplinary figure of the family, with potentially negative effects on children's school performance (Giannelli and Mangiavacchi, 2010). The negative effect of parental migration may, however, be mitigated by the role of the caregiver when parents migrate. Research on migrant parents in Southeast Asia (Battistella and Conaco, 1998; Jordan and Graham, 2012), subSaharan Africa (Cebotari and Mazzucato, 2016) and Eastern Europe (Robila, 2012; Vanore, 2015) found that a care arrangement that involves one parent, especially mothers, or grandparents, does not necessarily result in negative educational outcomes for children when parents migrate. The interchangeable relation between parental migration and the child's caregiver is therefore important and needs further investigation.

Most of the transnational family studies focus on the migration event and therefore offer little insights on children's outcomes when family members migrate and return. Understanding the effects of return migration is important because research notes difficulties for children upon the return of family members. For instance, Smith et al. (2004) found that the established bonds between children and their caregivers are challenged following the return of a migrant and may result in negative consequences for children. However, on a more positive note, both saving and remittances are usually higher if a migrant plans to return and these resources were found more likely to be invested in children upon the returnee's arrival (Antman, 2011). Furthermore, the concern about children and their outcomes was found to lead the return tendency of parents from abroad (Dustmann, 2003). Although considerable heterogeneity exists in the decision and motives to return, the resources and additional human capital that returnees bring back home are likely to positively mediate the educational development of children.

\subsection{Current study}

Taken together, the reviewed studies expose mixed results and reveal that the effects of living in transnational care on children's education do not support precise conclusions. There is work to be done to better understand circumstances under which school performance of children in transnational care improves or deteriorates. This study provides two additions to the existing scholarship. First, this study includes a variety of transnational family characteristics that potentially relate with children's school performance. Migrant-sending households are characterized by a wide range of transnational family settingsand therefore, each specific arrangement would likely influence children differently.
We look at these characteristics in two countries. A comparative framework is particularly useful because it offers a better understanding of how the diversity in transnational family forms associates with children's education in a wider regional context. Second, the current study employs two separate perspectives of school performance: that of caregivers and children themselves. Previous studies include perspectives of either the child or the caregiver, with one notable exception. Specifically, Jordan and Graham (2012) are the only scholars, to the best of our knowledge, to consider both perspectives in assessing children's school performance. They found a more negative assessment of school performance when the outcome was measured by the caregiver. These authors concluded that caregivers' assessments of the outcome may be altered by their personal experiences of the migration event and may persistently reflect more culturally informed perceptions of migration (Jordan and Graham, 2012). Therefore, we assume that there is sensitivity in reporting the outcome depending on who makes the assessment.

Based on evidence from earlier studies, several hypotheses are established:

Hypothesis 1. Children living in migrant or returned migrant households will be more likely than children living in non-migrant households to perform better in schools.

Hypothesis 2. Children with parents divorced, whether in the country or abroad, will likely perform less well in school than children living with both parents in the country.

Hypothesis 3. Maternal migration and the absence of both parents, irrespective of who is the caregiver, will likely associate with decreased school performance when compared to children living with both parents.

Hypothesis 4. Children living in households who receive remittances and prioritize remittances for education will likely perform better in schools than children living in non-migrant households.

\subsection{The contexts of Moldova and Georgia}

Moldova and Georgia are two post-Soviet countries bordering the Black Sea basin. Shortly after their independence from the Soviet Union in 1991, both countries began a difficult transition to a market economy that continues today. The loss of subsidies and the guaranteed access to the markets of the Soviet era led both countries to an economic decline. These problems were exacerbated by the outbreak of civil wars and the alternation of active and passive forms of conflict in the Transnistrian region of Moldova and in Abkhazia and the South Ossetia regions of Georgia, beginning shortly after independence and continuing today. As a result, there was a steep decline in living standards for the populations of the two countries.

Because of difficulties in the transition process, the migration of one or more family members has emerged as a livelihood strategy since the mid-1990s. In 2010, an estimated 25.1\% of the Georgian and $21.5 \%$ of the Moldovan populations have emigrated (World Bank, 2011). Many Georgians and Moldovans migrate to other former Soviet countries, most commonly to the Russian Federation. In the western world, favorite destinations for Moldovans are Italy, Romania, Spain and Portugal whereas Georgians prefer Greece, Turkey, the United States and Germany (World Bank, 2011). Most Georgians and Moldovans who migrate are working-age, skilled individuals: this characteristic holds true for both men and women, although more men migrate in Russia for seasonal work whereas more women migrate westward following the high demand for household services in the European Union countries (Labadze and Tukhashvili, 2013; UNICEF, 2016). More than 25\% of Moldovan migrants residing abroad have a wife or a husband who stay behind and approximately $36 \%(150,000-270,000)$ of all 
children in Moldova are believed to be separated from at least one parent because of migration (Svintradze and Ubiria, 2007). In Georgia, available data show that up to $39 \%$ of all children have at least one family member who is abroad (Vanore, 2015).

The education systems in both countries are universal and based on compulsory educational programs for all children. Georgian and Moldovan children start the school at age six and stay four years in elementary school. Middle school continues through the grades 5-9 up to the age of 15 , by which time the education is no longer compulsory. The final three years are reserved for secondary education, leading to diplomas granting access to tertiary education. On average, Georgian and Moldovan children stay in school 12.1 and 9.8 years, respectively (UNDP, 2013 ). Both countries have literacy rates of more than $99 \%$, and the number of students enrolled in primary, secondary and tertiary levels of education as a proportion of the total population has reached $74 \%$ in Georgia and 64\% in Moldova (as a result, Georgia ranks 79th and Moldova ranks 114th in the Human Development Index) (UNDP, 2013).

\section{Method}

\subsection{Data}

This study uses data from a nationally-representative, crosssectional, large-scale household survey in Moldova and Georgia. Fieldwork occurred between September 2011 and February 2012 in Moldova and between March and December 2012 in Georgia. In Moldova, the survey samples were drawn from the Moldovan Labor Force Survey (LFS) while in Georgia, the national representative sampling frame was elaborated based on electoral districts. All administrative regions were covered, except for Transnistria in Moldova and Abkhazia and South Ossetia in Georgia. The data collection followed the ethical standards of the International Code on Market and Social Research for Opinion and Market Research (ESOMAR).

The purpose of the survey was twofold. First, to empirically document the scale of migration and the prevalence of children "left-behind" in Georgia and Moldova. The migrant status was considered when members of the family were abroad for at least three months at the time of the survey. Second, to understand the complexity of life of children in transnational care and to measure the well-being of children in migrant and non-migrant households. Child well-being is measured through a variety of outcomes, including schooling, health, emotions and attitudes. Survey instruments included a household questionnaire administered to the head of the household, a questionnaire directed to the main caregiver of the indexed child (in some cases, this is the head of the household), and a child questionnaire targeting children and youths aged 11-19. All interviewees in the household gave informed consent to participate, and the survey was conducted in the local languages.

For this study, data are drawn from the child and caregiver questionnaires, except for household information that uses data from the household questionnaire. Only households with children of secondary school age (11-18) were retained for this study. Of the total sample, 541 households in Georgia and 664 households in Moldova contained at least one child aged 11-18; these households included 655 individual children in Georgia and 814 children in Moldova. These samples comprise children in both migrant and non-migrant households whose parents were in a stable marital relationship at the time of the survey. In addition, these samples do not comprise children whose parents are deceased $(\mathrm{N}=162$ in Moldova; $\mathrm{N}=89$ in Georgia). One analysis of this study additionally includes children in migrant and non-migrant households affected by divorce. For this particular analysis, the sample of children reached 926 and 773 observations in Moldova and Georgia, respectively. The measures, the analytical strategy and all models employed by this study are detailed below.

\subsection{Measures}

This study employs one measure of school performance based on the child-reports called the self-reported outcome and another measure based on the caregiver-reports. The child and caregiver questionnaires did not ask identical questions on children's school performance but we were able to select a measure from child reports that closely matched the caregiver-reports. The selfreported measure asked children the question "Would you say in your class you are one of the best students, above average, average, below average, or one of the worst students?" For analysis, a binary indicator was created where 1 indicates that the child is one of the best students or above average and all other options were coded as 0 . The second outcome measure was created from the caregivers' responses to the question "How would you say [child] is performing in school?" Responses were initially measured on a 5-point Likert scale (very well, well, neither well nor poorly, poorly, very poorly), and a binary indicator was created where 1 indicates very well and well. Following Jordan and Graham (2012), we consider the caregiver-reported and self-reported outcomes comparable because both indicators measure school performance relative to children's peers. The two measures were standardized as binary to better capture the positive and negative variations in the outcome and to simplify the comparison between the selfreported and the caregiver-reported indicators of school performance.

This study employs four independent variables that measure different transnational family arrangements of children in our sample. One indicator is based on questions in the migration history section that records information about the type of separation in relation to parental absence. These questions ask "Where is the biological [mother], [father] of [child]?" Detailed answers record specifics of parental absence: the parent is currently in the household; the parent is not currently living in the household: divorced/separated; the parent is not currently living in the household: living abroad; the parent is not currently living in the household: divorced and living abroad; the parent is not currently living in the household: deceased; and the parent is not currently living in the household: other. Based on this information, four types of parental absence were derived: both parents are together and live with the child, parents are in the country and divorced/separated, parents are abroad and together and parents are abroad and divorced/ separated.

The following three indicators focus specifically on children in families who were not affected by marital discord and subsequently omit children whose parents were divorced. Migration screening questions were used from the household rooster to record information regarding members currently residing in the household, members who are currently migrants and individuals who were previously migrants but returned. This information was used to classify households in three groups according to their household migration type: non-migrant, migrant and returned migrant. One additional measure records who is the migrant parent and the caregiver type of children by examining questions about parental migration history and the main caregiver of the child at the time of the survey. The information was used to classify parental migration and caregiver type in the following five categories: the child lives with both biological parents, the father is migrant and the mother is the caregiver, the mother is migrant and the father is the caregiver, and both parents are migrants and a grandparent is the caregiver. There were only five and two cases of children in Moldova and Georgia, respectively, who were cared for 
by a non-parental or a non-grandparental caregiver in our data. Given the small number of children who were cared by someone other than a parent or grandparent, this group is not included in the analytical sample. Finally, one indicator examines the availability of remittances and whether remittances are spent on education. Two questions are used to record this information. The first question asks: "Did the household receive any monetary or inkind remittances from the migrants - yes, no?" The second questions asks to list "the main use of money received from the migrant in the last 12 months." This information was used to construct an indicator with the following categories: a nonmigrant household, a migrant household who does not receive remittances, a migrant household who receives remittances and a migrant household who receives remittances and uses money for educational purposes.

Three variables measuring standardized characteristics of children were derived. Age was measured in full years and ranges between 11 and 18 . Gender of the child was included where 1 indicates girls. A binary measure of the child's health status when compared to other children of her/his age, as assessed by the caregiver, was included, where 1 indicates a much better or a better health.

An additional four measures summarize household socioeconomic status: a continuous indicator of completed years of

Table 1

Descriptive statistics (all variables: mean/proportions/standard deviations).

\begin{tabular}{|c|c|c|}
\hline & Moldova $^{a}$ & Georgia $^{\mathrm{b}}$ \\
\hline & $\begin{array}{l}\text { Percentage/ } \\
\text { mean (SD) }\end{array}$ & $\begin{array}{l}\text { Percentage/ } \\
\text { mean (SD) }\end{array}$ \\
\hline Increased school performance-caregiver reports (yes) & 74.20 & 72.52 \\
\hline Increased school performance-child reports (yes) & 42.75 & 54.20 \\
\hline \multicolumn{3}{|l|}{ Household type } \\
\hline Non-migrant household & 54.67 & 53.13 \\
\hline Migrant household & 29.24 & 37.56 \\
\hline Returned migrant household & 16.09 & 9.31 \\
\hline \multicolumn{3}{|l|}{ Type of Separation } \\
\hline Live with both parents: together & 68.47 & 63.52 \\
\hline Parents in the country: divorced/separated & 7.56 & 9.06 \\
\hline Parents abroad: together & 19.44 & 21.22 \\
\hline Parents abroad: divorced/separated & 4.54 & 6.21 \\
\hline \multicolumn{3}{|l|}{ Parental migration and child caregiver type } \\
\hline Live with both parents & 77.89 & 74.96 \\
\hline Father migrant, mother caregiver & 10.81 & 14.81 \\
\hline Mother migrant, father caregiver & 7.86 & 7.79 \\
\hline Both parents migrants, grandparent caregiver & 3.44 & 2.44 \\
\hline \multicolumn{3}{|l|}{ Remittances } \\
\hline Non-migrant household & 69.53 & 55.88 \\
\hline Migrant household: no & 9.83 & 10.99 \\
\hline Migrant household: yes & 15.97 & 18.93 \\
\hline Migrant household: yes, money spent on education & 4.67 & 14.20 \\
\hline$\%$ children female & 51.84 & 49.31 \\
\hline Child age (years) & $14.33(2.22)$ & $13.95(1.94)$ \\
\hline Child's health is better compared to other children (yes) & 42.14 & 63.82 \\
\hline Years of education of child's main caregiver & $11.15(2.52)$ & $13.02(2.51)$ \\
\hline Good living conditions (yes) & 78.62 & 73.13 \\
\hline Nr. of People divided by Nr. of Rooms & $1.27(0.68)$ & $1.39(0.88)$ \\
\hline Number of children in household & $1.82(1.03)$ & $1.90(0.84)$ \\
\hline Distance to school is more than $30 \mathrm{~min}$ (yes) & 23.10 & 14.50 \\
\hline Happiness status caregiver & $6.76(1.97)$ & $6.83(2.13)$ \\
\hline The child lives in urban area (yes) & 17.20 & 61.22 \\
\hline \multicolumn{3}{|l|}{ Region Moldova } \\
\hline Centre & 33.78 & \\
\hline Chisinau & 5.65 & \\
\hline North & 28.01 & \\
\hline South & 32.56 & \\
\hline \multicolumn{3}{|l|}{ Region Georgia } \\
\hline Tbilisi & & 28.09 \\
\hline Guria & & 3.36 \\
\hline Adjara & & 12.82 \\
\hline Shida-Kartli & & 6.41 \\
\hline Kaxeti & & 4.89 \\
\hline Kvemo-Kartli & & 11.30 \\
\hline Samegrelo & & 13.44 \\
\hline Imereti & & 13.13 \\
\hline Samcxe-Javaxeti & & 2.75 \\
\hline Mcxeta-Tianeti & & 3.82 \\
\hline
\end{tabular}

Note: Standard deviations in parentheses.

a All indicators in the Moldovan sample have 814 observations, except for the type of separation that has 926 observations.

b All indicators in the Georgian sample have 655 observations, except for the type of separation that has 773 observations. 
education of the child's main caregiver, a binary measure assessing the current living conditions of the household as viewed by the caregiver, a continuous measure of the housing quality which was constructed by dividing the total number of people living in the house by the total number of rooms used for living. Last but not least, the analysis also includes a measurement for the total number of children in the household.

Furthermore, one measure records the time-distance from home to school. This is a binary variable, where 1 indicates that it takes $30 \mathrm{~min}$ or more for children to reach the school. In addition, one family process indicator (Jordan and Graham, 2012; Vanore, 2015) measures the caregiver's happiness status on a ten-point Likert scale. Finally, the analysis includes a rural-urban variable and also a region indicator, because there may be geographical differences regarding education and migration in the target countries.

\subsection{Analytical strategy}

Given the binary expression of the dependent variables, this study employs binary logistic models to examine the association between the measures of school performance, transnational migration characteristics and selected controls. The results in all models are reported as odds ratios with confidence intervals. All models use sampling weights to adjust for eventual errors in the sampling design and to make data nationally representative.

Four different analyses were conducted based on the four transnational characteristics described above. Within each analysis, one transnational characteristic was regressed on the full set of controls. Separate analyses (not shown) were conducted where school performance has been hierarchically regressed on each transnational characteristic and the four sets of control variables. The results of the main predictors and model fit specifications were found stable after the inclusion of each cluster of indicators.

The analyses do not combine different transnational characteristics in one model for two reasons: a) we intend to capture the specific effect of each transnational measurement without the interfering effects of other transnational settings; and b) each transnational characteristic is constructed in such a way that it compares children in transnational and non-transnational households. This makes primary predictors collinear because they each contain a number of children living in non-migrant households. Children in non-migrant households are explicitly kept as the reference category because we want to capture the school performance effects in a wider population than just migrant families.

Except for one analysis which focuses on parental migration and divorce, all other analyses isolate the role of migration as a unique form of absence and exclude those children whose parents are away in the country or abroad and are divorced ( $N=112$ in Moldova; $\mathrm{N}=118$ in Georgia). Bivariate means comparison tests did not find differences in the means of the main predictors when comparing excluded and non-excluded observations, suggesting that exclusions were missing at random.

A multilevel modelling approach was initially considered but the tests for the intraclass correlation estimates (ICC) showed limited variation of cases when regions in the countries were considered at the second level of analysis. However, indicators specifying regions and the rural-urban location were included as fixed effects to account for unobserved differences in each country. All measurements in the models were tested for collinearity, and none was detected: the variation inflation factors (VIF) scored between 1 and 1.4, and the tolerance values were average.

\section{Results}

For brevity, we only discuss descriptive findings pertaining to transnational characteristics and dependent variables (Table 1 and Table 2). Within the analytical sample, the proportions of Moldovan and Georgian children living in migrant families account for $29.24 \%$ and $37.56 \%$, respectively. In addition, a noticeable proportion of Moldovan and Georgian children live in returned migrant households (16.09\% and $9.31 \%$, respectively). In the data, $19.44 \%$ of Moldovan children and $21.22 \%$ of Georgian children have at least one parent abroad and in a stable marital relationship. By contrast, $4.54 \%$ of Moldovan children and $6.21 \%$ of Georgian children have their parents abroad and divorced. Of those children with a migrant parent abroad, the greatest proportion have their father away and the mother caregiver. Children with both parents

Table 2

Proportions of children in different transnational care arrangements by school performance.

\begin{tabular}{|c|c|c|c|c|c|c|c|c|c|c|}
\hline & \multicolumn{10}{|c|}{ Increased school performance } \\
\hline & \multicolumn{5}{|c|}{ Moldova } & \multicolumn{5}{|c|}{ Georgia } \\
\hline & CR & Test statistic & SR & Test statistic & No. Obs. & $\mathrm{CR}$ & Test statistic & SR & Test statistic & No. Obs. \\
\hline Household type & & 3.21 & & 3.80 & 814 & & 1.21 & & 3.08 & 655 \\
\hline Non-migrant household & 72.36 & & 39.78 & & 445 & 73.85 & & 56.32 & & 348 \\
\hline Migrant household & 74.37 & & 45.38 & & 238 & 71.95 & & 53.66 & & 246 \\
\hline Returned migrant household & 80.15 & & 48.09 & & 131 & 67.21 & & 44.26 & & 61 \\
\hline Type of Separation & & 3.69 & & $14.44^{* * *}$ & 926 & & 9.71 & & $7.93^{*}$ & 773 \\
\hline Live with both parents: married/together & 73.19 & & 40.69 & & 634 & 73.52 & & 55.60 & & 491 \\
\hline Parents in the country: divorced/separated & 67.14 & & 30 & & 70 & 64.29 & & 54.29 & & 70 \\
\hline Parents abroad and together & 77.78 & & 50 & & 180 & 69.51 & & 50 & & 164 \\
\hline Parents abroad and divorced/separated & 78.57 & & 59.52 & & 42 & 54.17 & & 35.42 & & 48 \\
\hline Parental migration and child caregiver type & & 1.62 & & 5.35 & 814 & & 1.94 & & 1.83 & 655 \\
\hline Live with both parents & 73.19 & & 40.69 & & 634 & 73.52 & & 55.60 & & 491 \\
\hline Father migrant, mother caregiver & 78.41 & & 52.27 & & 88 & 67.01 & & 49.48 & & 97 \\
\hline Mother migrant, father caregiver & 76.56 & & 48.44 & & 64 & 74.51 & & 49.02 & & 51 \\
\hline Both parents migrants, grandparent caregiver & 78.57 & & 46.43 & & 28 & 68.75 & & 56.25 & & 16 \\
\hline Remittances & & 3.81 & & $6.58^{*}$ & 814 & & 3.05 & & $14.79^{* * *}$ & 655 \\
\hline Non-migrant household & 74.73 & & 41.52 & & 566 & 73.50 & & 56.01 & & 366 \\
\hline Migrant household: no & 66.25 & & 36.25 & & 80 & 69.44 & & 38.89 & & 72 \\
\hline Migrant household: yes & 74.62 & & 47.69 & & 130 & 67.74 & & 48.39 & & 124 \\
\hline Migrant household: yes, money spent on education & 81.58 & & 57.89 & & 38 & 77.42 & & 66.67 & & 93 \\
\hline
\end{tabular}

Note. Chi-squared tests were used for all comparisons; $\mathrm{CR}=$ caregiver-report; $\mathrm{SR}=$ self-report.

${ }^{*} p<0.05,{ }^{* *} p<0.01,{ }^{* * *} p<0.001$. 
abroad and cared for by a grandparent account for $3.44 \%$ and $2.44 \%$ in Moldova and Georgia, respectively. In Moldova, $15.97 \%$ of children live in migrant families that receive remittances, compared to $18.93 \%$ in Georgia. The proportion of children living in migrant households who prioritize remittances for education is higher in Georgia than in Moldova (14.2\% vs. 4.67\%, respectively).

In general, the proportions of children with increased school performance based on caregiver-reports is considerably higher overall compared to the proportions derived from children's reports, although children in transnational care were still assessed as doing better in schools compared to those in non-migrant families (Table 2). Across the transnational measures presented in Table 2, there are statistically significant differences only for children's self-reports for the type of separation and remittances. These reports show that children with divorced parents in the country (Moldova) or abroad (Georgia) and those in households that do not receive remittances are less likely to report better school performance.

The bivariate results provide exploratory insights on the differences between children's reports and caregiver-reports across different transnational characteristics. However, multivariate regression models are fitted to test the combined effects of all controls in relation to children's school performance. Extracts from the final logistic regression models are presented in Tables 3-6. The data reveal both similarities and differences across transnational characteristics and across self-reports and caregiver-reports. The first analysis assesses the relationship between the household type and children's school performance (Table 3). The evidence based on both self- and caregiver-reports shows no differing effects of school performance when children in a migrant or a returnmigrant household are considered in relation to children in nonmigrant households. Hypothesis 1 is thus rejected.

The second analysis disaggregates the type of parental absence into four forms: both parents are together and live with the child, parents are in the country and divorced, parents are abroad and together and parents are abroad and divorced (Table 4). Results show that the type of separation has significant bearing on children's school performance, although it depends on the country and on who makes the assessment. After accounting for all the controls, there is evidence that Moldovan children are more likely to report better school performance when parents are abroad and either together or divorced. The relative effect size of the dimension "parents abroad and divorced" $(\mathrm{OR}=2.52)$ is larger than for the category "parents abroad and together" $(\mathrm{OR}=1.68)$. In Georgia, there is no evidence of a marital status effect of migrant and non-migrant parents in relation to children's school performance. These results run counter to Hypothesis 2, which is therefore rejected.

The third analysis looked at who is the migrant parent and who is the caregiver of children in transnational care (Table 5). In Moldova, self-reports show that paternal migration, when mothers are caregivers, is associated with increased school performance. In Georgia, to the contrary, assessments based on either caregiver or self-reports show that children with fathers abroad and cared for by mothers are less likely to perform well in school. Notably, there is no evidence of adverse effects on children's school performance when mothers migrate and fathers are caregivers or when both parents migrate and grandparents are caregivers. This finding is

Table 3

Household type and children's school performance.

\begin{tabular}{|c|c|c|c|c|c|c|c|c|}
\hline & \multicolumn{4}{|c|}{ Moldova } & \multicolumn{4}{|l|}{ Georgia } \\
\hline & \multicolumn{2}{|c|}{ Caregiver-report } & \multicolumn{2}{|c|}{ Self-report } & \multicolumn{2}{|c|}{ Caregiver-report } & \multicolumn{2}{|c|}{ Self-report } \\
\hline & OR & $\mathrm{CI}$ & OR & $\mathrm{CI}$ & OR & $\mathrm{CI}$ & OR & $\mathrm{CI}$ \\
\hline \multicolumn{9}{|l|}{ Household type (ref. Non-migrant household) } \\
\hline Migrant household & 0.90 & {$[0.59,1.37]$} & 1.31 & {$[0.89,1.93]$} & 0.75 & {$[0.43,1.31]$} & 0.77 & {$[0.47,1.26]$} \\
\hline Returned migrant household & 1.23 & {$[0.69,2.20]$} & 1.42 & {$[0.86,2.34]$} & 0.71 & {$[0.30,1.68]$} & 0.77 & {$[0.33,1.76]$} \\
\hline Child is girl & $2.55^{* * *}$ & {$[1.75,3.72]$} & $2.89^{* * *}$ & {$[2.04,4.08]$} & $2.59^{* * *}$ & {$[1.57,4.29]$} & $3.29^{* * *}$ & {$[2.09,5.19]$} \\
\hline Child age (in years) & 0.92 & {$[0.84,1.01]$} & 0.93 & {$[0.85,1.01]$} & $0.80^{* * *}$ & {$[0.70,0.90]$} & $0.82^{* *}$ & {$[0.74,0.92]$} \\
\hline The child is healthy & 1.26 & {$[0.85,1.87]$} & $1.50^{*}$ & {$[1.07,2.11]$} & 1.52 & {$[0.87,2.65]$} & 1.13 & {$[0.66,1.92]$} \\
\hline Years of education of child's main caregiver & $1.19^{* * *}$ & {$[1.08,1.30]$} & $1.12^{* *}$ & {$[1.03,1.21]$} & $1.29^{* * *}$ & {$[1.14,1.45]$} & $1.31^{* * *}$ & {$[1.18,1.45]$} \\
\hline Good living conditions & 1.53 & {$[0.97,2.42]$} & 1.13 & {$[0.71,1.77]$} & 1.61 & {$[0.88,2.92]$} & 1.22 & {$[0.71,2.07]$} \\
\hline Nr. of People per Nr. of Rooms & 0.78 & {$[0.60,1.02]$} & 0.90 & {$[0.67,1.22]$} & 0.96 & {$[0.74,1.25]$} & 0.79 & {$[0.59,1.04]$} \\
\hline Number of children in household & 0.96 & {$[0.77,1.19]$} & 0.93 & {$[0.76,1.13]$} & 1.11 & {$[0.82,1.49]$} & 0.79 & {$[0.59,1.05]$} \\
\hline Distance to school & 0.98 & {$[0.64,1.48]$} & 0.92 & {$[0.61,1.38]$} & 1.02 & {$[0.52,1.99]$} & 0.69 & {$[0.37,1.28]$} \\
\hline Happiness status caregiver & $1.15^{* *}$ & {$[1.04,1.28]$} & $1.12^{*}$ & {$[1.01,1.23]$} & 0.99 & {$[0.88,1.11]$} & 1.04 & {$[0.93,1.16]$} \\
\hline The child lives in urban area & 1.42 & {$[0.81,2.49]$} & 0.92 & {$[0.55,1.54]$} & 1.02 & {$[0.58,1.81]$} & 1.08 & {$[0.63,1.86]$} \\
\hline \multicolumn{9}{|l|}{ Region Moldova (ref. Centre) } \\
\hline Chisinau & $0.33^{*}$ & {$[0.13,0.83]$} & 1.05 & {$[0.47,2.36]$} & & & & \\
\hline North & 0.91 & {$[0.57,1.47]$} & 1.00 & {$[0.64,1.55]$} & & & & \\
\hline South & 0.81 & {$[0.52,1.26]$} & 0.78 & {$[0.52,1.17]$} & & & & \\
\hline \multicolumn{9}{|l|}{ Region Georgia (ref. Tbilisi) } \\
\hline Guria & & & & & 0.60 & {$[0.14,2.48]$} & 0.60 & {$[0.16,2.26]$} \\
\hline Adjara & & & & & $0.35^{* *}$ & {$[0.16,0.76]$} & $0.19^{* * *}$ & {$[0.09,0.41]$} \\
\hline Shida-Kartli & & & & & 0.90 & {$[0.29,2.74]$} & $0.26^{*}$ & {$[0.09,0.75]$} \\
\hline Kaxeti & & & & & 0.82 & {$[0.17,3.88]$} & $0.26^{*}$ & {$[0.09,0.78]$} \\
\hline Kvemo-Kartli & & & & & 0.57 & {$[0.21,1.53]$} & $0.38^{*}$ & {$[0.16,0.91]$} \\
\hline Samegrelo & & & & & 2.37 & {$[0.85,6.57]$} & 0.80 & {$[0.34,1.87]$} \\
\hline Imereti & & & & & 0.45 & {$[0.20,1.03]$} & 0.88 & {$[0.40,1.93]$} \\
\hline Samcxe-Javaxeti & & & & & 0.29 & {$[0.07,1.19]$} & 1.17 & {$[0.26,5.10]$} \\
\hline Mcxeta-Tianeti & & & & & $0.24^{*}$ & {$[0.07,0.79]$} & 0.47 & {$[0.13,1.61]$} \\
\hline McFadden's pseudo- $R^{2}$ & 0.11 & & 0.09 & & 0.18 & & 0.20 & \\
\hline $\mathrm{N}$ & 814 & & 814 & & 655 & & 655 & \\
\hline
\end{tabular}

Note: $\mathrm{OR}=$ odds ration; $\mathrm{CI}=95 \%$ confidence intervals in brackets; All samples in this analysis exclude children whose parents are divorced.

${ }^{*} p<0.05,{ }^{* *} p<0.01,{ }^{* * *} p<0.001$. 
Table 4

Type of separation and children's school performance.

\begin{tabular}{|c|c|c|c|c|c|c|c|c|}
\hline & \multicolumn{4}{|c|}{ Moldova } & \multicolumn{4}{|l|}{ Georgia } \\
\hline & \multicolumn{2}{|c|}{ Caregiver-report } & \multicolumn{2}{|c|}{ Self-report } & \multicolumn{2}{|c|}{ Caregiver-report } & \multicolumn{2}{|c|}{ Self-report } \\
\hline & OR & $\mathrm{CI}$ & OR & $\mathrm{CI}$ & OR & $\mathrm{CI}$ & OR & $\mathrm{CI}$ \\
\hline \multicolumn{9}{|c|}{ Type of separation (ref. Live with both parents: married/together) } \\
\hline Parents in the country: divorced/separated & 0.83 & {$[0.42,1.63]$} & 0.51 & {$[0.25,1.01]$} & 0.45 & {$[0.20,1.04]$} & 0.54 & {$[0.24,1.23]$} \\
\hline Parents abroad: together & 1.13 & {$[0.71,1.81]$} & $1.68^{* *}$ & {$[1.13,2.48]$} & 0.53 & {$[0.28,1.02]$} & 0.45 & {$[0.25,0.83]$} \\
\hline Parents abroad: divorced/separated & 0.88 & {$[0.33,2.31]$} & $2.52^{*}$ & {$[1.17,5.40]$} & 0.58 & {$[0.21,1.58]$} & 0.89 & {$[0.33,2.38]$} \\
\hline Child is girl & $2.98^{* * *}$ & {$[2.07,4.28]$} & $2.84^{* * *}$ & {$[2.04,3.95]$} & $2.27^{* * *}$ & {$[1.44,3.58]$} & $2.99^{* * *}$ & {$[1.97,4.55]$} \\
\hline Child age (in years) & 0.94 & {$[0.81,1.02]$} & 0.92 & {$[0.85,0.99]$} & $0.80^{* * *}$ & {$[0.72,0.89]$} & $0.85^{* *}$ & {$[0.77,0.94]$} \\
\hline The child is healthy & $1.51^{*}$ & {$[1.06,2.19]$} & $1.58^{* *}$ & {$[1.14,2.18]$} & 1.51 & {$[0.93,2.46]$} & 1.04 & {$[0.65,1.65]$} \\
\hline Years of education of child's main caregiver & $1.17^{* * *}$ & {$[1.08,1.27]$} & $1.14^{* * *}$ & {$[1.06,1.22]$} & $1.18^{* * *}$ & {$[1.07,1.31]$} & $1.18^{* * *}$ & {$[1.09,1.29]$} \\
\hline Good living conditions & $1.72^{*}$ & {$[1.12,2.63]$} & 1.37 & {$[0.89,2.11]$} & 1.40 & {$[0.81,2.43]$} & 1.06 & {$[0.66,1.73]$} \\
\hline Nr. of People per Nr. of Rooms & $0.76^{*}$ & {$[0.59,0.99]$} & 0.90 & {$[0.69,1.19]$} & 0.89 & {$[0.70,1.13]$} & $0.73^{*}$ & {$[0.56,0.94]$} \\
\hline Number of children in household & 1.00 & {$[0.81,1.23]$} & 0.93 & {$[0.77,1.11]$} & 1.08 & {$[0.82,1.42]$} & 0.83 & {$[0.64,1.09]$} \\
\hline Distance to school & 1.21 & {$[0.80,1.81]$} & 1.05 & {$[0.71,1.54]$} & 1.16 & {$[0.61,2.21]$} & 0.77 & {$[0.43,1.36]$} \\
\hline Happiness status caregiver & 1.08 & {$[0.98,1.19]$} & 1.08 & {$[0.99,1.18]$} & 1.02 & {$[0.92,1.13]$} & 1.05 & {$[0.95,1.16]$} \\
\hline The child lives in urban area & 1.17 & {$[0.71,1.92]$} & 0.86 & {$[0.54,1.37]$} & 1.09 & {$[0.65,1.81]$} & 1.17 & {$[0.71,1.94]$} \\
\hline \multicolumn{9}{|l|}{ Region Moldova (ref. Centre) } \\
\hline Chisinau & 0.45 & {$[0.20,1.01]$} & 0.99 & {$[0.46,2.11]$} & & & & \\
\hline North & 0.92 & {$[0.59,1.44]$} & 0.95 & {$[0.62,1.43]$} & & & & \\
\hline South & 0.98 & {$[0.64,1.49]$} & 0.78 & {$[0.53,1.14]$} & & & & \\
\hline \multicolumn{9}{|l|}{ Region Georgia (ref. Tbilisi) } \\
\hline Guria & & & & & 0.35 & {$[0.10,1.15]$} & 0.34 & {$[0.10,1.16]$} \\
\hline Adjara & & & & & $0.32^{* *}$ & {$[0.15,0.65]$} & $0.17^{* * *}$ & {$[0.08,0.34]$} \\
\hline Shida-Kartli & & & & & 0.85 & {$[0.30,2.36]$} & $0.22^{* *}$ & {$[0.08,0.57]$} \\
\hline Kaxeti & & & & & 0.76 & {$[0.17,3.35]$} & $0.25^{* *}$ & {$[0.09,0.68]$} \\
\hline Kvemo-Kartli & & & & & $0.38^{*}$ & {$[0.16,0.89]$} & $0.25^{* * *}$ & {$[0.12,0.55]$} \\
\hline Samegrelo & & & & & 1.49 & {$[0.64,3.48]$} & 0.62 & {$[0.29,1.32]$} \\
\hline Imereti & & & & & $0.38^{*}$ & {$[0.18,0.82]$} & 0.72 & {$[0.35,1.48]$} \\
\hline Samcxe-Javaxeti & & & & & $0.24^{*}$ & {$[0.07,0.83]$} & 1.13 & {$[0.29,4.34]$} \\
\hline Mcxeta-Tianeti & & & & & 0.33 & {$[0.10,1.07]$} & 0.60 & {$[0.18,1.98]$} \\
\hline McFadden's pseudo- $\mathrm{R}^{2}$ & 0.12 & & 0.11 & & 0.15 & & 0.17 & \\
\hline $\mathrm{N}$ & 926 & & 926 & & 773 & & 773 & \\
\hline
\end{tabular}

Note: $\mathrm{OR}=$ odds ration; $\mathrm{CI}=95 \%$ confidence intervals in brackets.

${ }^{*} p<0.05,{ }^{* *} p<0.01,{ }^{* * *} p<0.001$.

important because it shows that specific care arrangements involving a family member may help provide resilience to children when their primary caregiver, the mother, migrates. Based on this evidence, we reject Hypothesis 3.

The final analysis provides evidence of the relationship between remittances and children's school performance. The results indicate a negative association between the absence of remittances and children's education, but only in Moldova and based on caregiver-reports (Table 6). The absence of a similar perception from Moldovan children may suggest that caregivers may sense the lack of remittances more acutely in their role as caregivers and providers for children. In Georgia, remittances do not correspond to significant differences in relation to children's education. Contrary to our expectation, results in both countries do not show significant associations between prioritizing remittances for education and improved school performance. Based on this evidence, we reject Hypothesis 4.

The school performance of children should also be understood within the context of other confounders. Few controls are statistically significant throughout models. Girls are found to perform better at school than boys. Age is found to negatively associate with school performance in Georgia but not in Moldova. Children in good health fare better in schools in Moldova. The indicator measuring the years of education of children's main caregiver positively associates with children's education in both countries. The happiness status of the caregiver is a positive predictor for children's school performance in Moldova but not in Georgia.
A series of interactions (not shown) were tested between the gender of the child and the transnational characteristics. No significant and stable interactions that improved model fit were observed across models. In Moldova, the gender interacted with the status of divorce when parents are at home is associated with better school performance for girls, according to caregiver reports. In Georgia, interaction terms based on caregiver reports show that girls in migrant households do better in school compared to boys in a similar transnational setting. By contrast, interaction terms based on child reports show that girls whose mother migrated and are cared for by fathers are less likely to do well in school in Georgia. On the grounds of parsimony these interactions are not presented in the final models.

\section{Discussion}

Migration of family members is a common solution for achieving a decent standard of living for many households in the former Soviet Union countries. As migration unfolds, the attention of both academics and policy makers has focused on the outcomes of children who stay behind and how they experience the separation when one or more family members are seeking to better their lives abroad. Although children may experience separation and loss, staying behind also offers some advantages because children remain embedded in familiar family settings and may benefit from the economic and social resources from abroad. Nevertheless, children in transnational care are vulnerable and the lack of parental input and supervision may affect specific 
Table 5

Parental migration, the caregiver type and children's school performance.

\begin{tabular}{|c|c|c|c|c|c|c|c|c|}
\hline & \multicolumn{4}{|c|}{ Moldova } & \multicolumn{4}{|l|}{ Georgia } \\
\hline & \multicolumn{2}{|c|}{ Caregiver-report } & \multicolumn{2}{|c|}{ Self-report } & \multicolumn{2}{|c|}{ Caregiver-report } & \multicolumn{2}{|c|}{ Self-report } \\
\hline & OR & $\mathrm{CI}$ & OR & $\mathrm{CI}$ & OR & $\mathrm{CI}$ & OR & $\mathrm{CI}$ \\
\hline \multicolumn{9}{|c|}{ Parental migration and child caregiver type (ref. Live with both parents) } \\
\hline Father migrant: mother caregiver & 1.15 & {$[0.63,2.07]$} & $1.71^{*}$ & {$[1.01,2.89]$} & $0.37^{*}$ & {$[0.16,0.83]$} & $0.29^{* * *}$ & {$[0.14,0.59]$} \\
\hline Mother migrant: father caregiver & 1.07 & {$[0.51,2.24]$} & 1.73 & {$[0.94,3.12]$} & 1.89 & {$[0.71,5.01]$} & 1.11 & {$[0.40,3.05]$} \\
\hline Both parents abroad: grandparent caregiver & 2.06 & {$[0.62,6.87]$} & 1.88 & {$[0.81,4.36]$} & 0.23 & {$[0.06,0.88]$} & 0.46 & {$[0.10,2.09]$} \\
\hline Child is girl & $2.49^{* * * *}$ & {$[1.70,3.64]$} & $2.85^{* * *}$ & {$[2.02,4.04]$} & $2.64^{* * *}$ & {$[1.59,4.39]$} & $3.31^{* * *}$ & {$[2.10,5.22]$} \\
\hline Child age (in years) & 0.92 & {$[0.84,1.01]$} & 0.93 & {$[0.85,1.01]$} & $0.80^{* * *}$ & {$[0.71,0.91]$} & $0.83^{* *}$ & {$[0.74,0.93]$} \\
\hline The child is healthy & $1.27^{*}$ & {$[0.86,1.89]$} & $1.49^{*}$ & {$[1.06,2.10]$} & 1.49 & {$[0.86,2.58]$} & 1.11 & {$[0.65,1.89]$} \\
\hline Years of education of child's main caregiver & $1.19^{* * *}$ & {$[1.09,1.31]$} & $1.13^{* *}$ & {$[1.04,1.22]$} & $1.29^{* * *}$ & {$[1.14,1.45]$} & $1.31^{* * *}$ & {$[1.18,1.45]$} \\
\hline Good living conditions & 1.49 & {$[0.94,2.36]$} & 1.11 & {$[0.70,1.76]$} & 1.56 & {$[0.84,2.87]$} & 1.20 & {$[0.70,2.06]$} \\
\hline Nr. of People per Nr. of Rooms & 0.79 & {$[0.60,1.04]$} & 0.91 & {$[0.67,1.23]$} & 0.98 & {$[0.74,1.29]$} & 0.77 & {$[0.58,1.03]$} \\
\hline Number of children in household & 0.97 & {$[0.78,1.20]$} & 0.95 & {$[0.78,1.15]$} & 1.09 & {$[0.80,1.47]$} & 0.77 & {$[0.58,1.04]$} \\
\hline Distance to school & 0.97 & {$[0.64,1.47]$} & 0.94 & {$[0.63,1.40]$} & 1.01 & {$[0.51,1.99]$} & 0.69 & {$[0.37,1.30]$} \\
\hline Happiness status caregiver & $1.16^{* *}$ & {$[1.05,1.29]$} & $1.12^{*}$ & {$[1.02,1.23]$} & 0.99 & {$[0.88,1.11]$} & 1.04 & {$[0.94,1.17]$} \\
\hline The child lives in urban area & 1.43 & {$[0.82,2.49]$} & 0.92 & {$[0.55,1.54]$} & 0.99 & {$[0.56,1.77]$} & 1.08 & {$[0.63,1.87]$} \\
\hline \multicolumn{9}{|l|}{ Region Moldova (ref. Centre) } \\
\hline Chisinau & $0.35^{*}$ & {$[0.14,0.88]$} & 1.10 & {$[0.48,2.49]$} & & & & \\
\hline North & 0.91 & {$[0.56,1.48]$} & 1.01 & {$[0.65,1.58]$} & & & & \\
\hline South & 0.77 & {$[0.50,1.20]$} & 0.78 & {$[0.52,1.17]$} & & & & \\
\hline \multicolumn{9}{|l|}{ Region Georgia (ref. Tbilisi) } \\
\hline Guria & & & & & 0.59 & {$[0.14,2.52]$} & 0.55 & {$[0.14,2.17]$} \\
\hline Adjara & & & & & $0.33^{* *}$ & {$[0.15,0.74]$} & $0.17^{* * *}$ & {$[0.08,0.38]$} \\
\hline Shida-Kartli & & & & & 0.85 & {$[0.27,2.60]$} & $0.24^{* *}$ & {$[0.08,0.69]$} \\
\hline Kaxeti & & & & & 0.77 & {$[0.16,3.61]$} & $0.24^{*}$ & {$[0.08,0.72]$} \\
\hline Kvemo-Kartli & & & & & 0.58 & {$[0.22,1.52]$} & $0.36^{*}$ & {$[0.15,0.88]$} \\
\hline Samegrelo & & & & & 2.23 & {$[0.81,6.08]$} & 0.75 & {$[0.32,1.72]$} \\
\hline Imereti & & & & & $0.41^{*}$ & {$[0.18,0.92]$} & 0.80 & {$[0.36,1.75]$} \\
\hline Samcxe-Javaxeti & & & & & 0.28 & {$[0.07,1.13]$} & 1.10 & {$[0.25,4.83]$} \\
\hline Mcxeta-Tianeti & & & & & $0.21 *$ & {$[0.06,0.70]$} & 0.44 & {$[0.12,1.53]$} \\
\hline McFadden's pseudo- $\mathrm{R}^{2}$ & 0.12 & & 0.10 & & 0.19 & & 0.21 & \\
\hline $\mathrm{N}$ & 814 & & 814 & & 655 & & 655 & \\
\hline
\end{tabular}

Note: $\mathrm{OR}=$ odds ration; $\mathrm{CI}=95 \%$ confidence intervals in brackets; All samples in this analysis exclude children whose parents are divorced.

${ }^{*} p<0.05,{ }^{* *} p<0.01,{ }^{* * *} p<0.001$.

outcomes, such as children's performance in school. The evidence from existent scholarship is mixed, with no studies so far looking at self- and caregiver-reported measures of school performance in Moldova and Georgia.

This study brings evidence of the effects of transnational family life on children's education and adds two reflections to the current knowledge. First, it is important to distinguish between different transnational family forms because they nuance the effects of migration on children's education. While on the whole results show that living transnationally does not necessarily associate with worse outcomes, particular transnational forms of living do show a greater vulnerability of children in relation to their school performance. Specifically, we found two instances when children's education is negatively affected by migration. In Moldova, caregivers perceived the absence of remittances as worsening children's performance in school. Even when Moldovan and Georgian households received remittances and spent more on education, there were no significant improvement in children's school performance. This may relate with the volatile nature of remittances in the two contexts. Our data show that $32 \%$ and $30 \%$ of Moldovan and Georgian migrants, respectively, do not have a valid residence and work permit in the country of destination, which may reflect the volume of underpaid and sometimes illegal work that migrants perform to earn a living and to support their family members back home. We also found a negative association between school performance and paternal migration when mothers were caregivers in Georgia. In Moldova, to the contrary, children reported better school performance when fathers migrated and mothers were caregivers. This is an intriguing finding considering that in both countries it is often mothers who take the leading role in raising children, including educational duties while the traditional role of fathers is earning money (Vanore, 2015). The composition of transnational households in Moldova and Georgia does appear to be rather different, which may explain the differing results. Specifically, Georgian children in transnational families live on average with more siblings at home and reside in more crowded conditions compared to Moldovan children. Furthermore, our data show higher proportions of elderly family members that reside in migrant households in Georgia compared to Moldova (12.2\% and 5.3\%, respectively). The higher prevalence of multigenerational households in Georgia than in Moldova reflects increased responsibilities for Georgian women, including caring for more children and elderly when husbands migrate. Children in these households are therefore less likely to receive adequate supervision and academic assistance which may reflect negatively on their school performance. Our findings mirror earlier research conducted in Georgia that shows children developing severe behavioral problems and performing less well in schools when fathers migrate (Svintradze and Ubiria, 2007).

Beyond the negative effects from migration, this study also reveals that maternal migration, when fathers or grandparents are caregivers, does not seem to negatively affect children's school performance in the two countries in focus in this study. This finding contradicts the dominant narrative characterizing maternal migration as detrimental for children (Battistella and Conaco, 1998; Cortes, 2015; Parreñas, 2005). Instead, it emphasizes the role 
Table 6

Remittances and children's school performance.

\begin{tabular}{|c|c|c|c|c|c|c|c|c|}
\hline & \multicolumn{4}{|c|}{ Moldova } & \multicolumn{4}{|l|}{ Georgia } \\
\hline & \multicolumn{2}{|c|}{ Caregiver-report } & \multicolumn{2}{|c|}{ Self-report } & \multicolumn{2}{|c|}{ Caregiver-report } & \multicolumn{2}{|c|}{ Self-report } \\
\hline & OR & $\mathrm{CI}$ & OR & $\mathrm{CI}$ & OR & $\mathrm{CI}$ & OR & $\mathrm{Cl}$ \\
\hline \multicolumn{9}{|l|}{ Remittances (ref. Non-migrant household) } \\
\hline Migrant household: no & $0.52^{*}$ & {$[0.29,0.94]$} & 0.97 & {$[0.51,1.85]$} & 1.22 & {$[0.55,2.70]$} & 0.76 & {$[0.39,1.47]$} \\
\hline Migrant household: yes & 0.82 & {$[0.48,1.37]$} & 1.18 & {$[0.72,1.93]$} & 0.60 & {$[0.32,1.12]$} & 0.52 & {$[0.28,0.93]$} \\
\hline Migrant household: yes, money spent on education & 0.97 & {$[0.36,2.57]$} & 1.96 & {$[0.89,4.28]$} & 0.83 & {$[0.31,2.24]$} & 1.20 & {$[0.52,2.79]$} \\
\hline Child is girl & $2.56^{* * *}$ & {$[1.75,3.74]$} & $2.89^{* * *}$ & {$[2.03,4.09]$} & $2.62^{* * *}$ & {$[1.58,4.34]$} & $3.34^{* * *}$ & {$[2.12,5.27]$} \\
\hline Child age (in years) & 0.92 & {$[0.84,1.01]$} & 0.93 & {$[0.85,1.01]$} & $0.80^{* * *}$ & {$[0.71,0.91]$} & $0.83^{* *}$ & {$[0.74,0.93]$} \\
\hline The child is healthy & 1.29 & {$[0.87,1.92]$} & $1.50^{*}$ & {$[1.06,2.11]$} & 1.49 & {$[0.86,2.58]$} & 1.09 & {$[0.64,1.86]$} \\
\hline Years of education of child's main caregiver & $1.18^{* * *}$ & {$[1.08,1.29]$} & $1.12^{* *}$ & {$[1.03,1.21]$} & $1.30^{* * *}$ & {$[1.15,1.47]$} & $1.31^{* * *}$ & {$[1.18,1.46]$} \\
\hline Good living conditions & 1.57 & {$[0.99,2.50]$} & 1.14 & {$[0.72,1.80]$} & 1.58 & {$[0.87,2.89]$} & 1.18 & {$[0.69,2.02]$} \\
\hline Nr. of People per Nr. of Rooms & 0.77 & {$[0.58,1.01]$} & 0.90 & {$[0.66,1.22]$} & 0.97 & {$[0.74,1.27]$} & 0.79 & {$[0.60,1.06]$} \\
\hline Number of children in household & 0.96 & {$[0.77,1.19]$} & 0.94 & {$[0.77,1.14]$} & 1.10 & {$[0.82,1.48]$} & 0.78 & {$[0.58,1.05]$} \\
\hline Distance to school & 0.97 & {$[0.64,1.47]$} & 0.91 & {$[0.60,1.36]$} & 1.01 & {$[0.51,1.97]$} & 0.68 & {$[0.37,1.27]$} \\
\hline Happiness status caregiver & $1.15^{* *}$ & {$[1.04,1.28]$} & $1.12^{*}$ & {$[1.01,1.23]$} & 0.99 & {$[0.88,1.11]$} & 1.04 & {$[0.93,1.16]$} \\
\hline The child lives in urban area & 1.42 & {$[0.81,2.50]$} & 0.94 & {$[0.57,1.57]$} & 1.01 & {$[0.57,1.78]$} & 1.06 & {$[0.62,1.83]$} \\
\hline \multicolumn{9}{|l|}{ Region Moldova (ref. Centre) } \\
\hline Chisinau & $0.35^{*}$ & {$[0.14,0.87]$} & 1.03 & {$[0.46,2.34]$} & & & & \\
\hline North & 0.90 & {$[0.56,1.46]$} & 0.98 & {$[0.63,1.54]$} & & & & \\
\hline South & 0.85 & {$[0.54,1.33]$} & 0.78 & {$[0.52,1.17]$} & & & & \\
\hline \multicolumn{9}{|l|}{ Region Georgia (ref. Tbilisi) } \\
\hline Guria & & & & & 0.59 & {$[0.14,2.42]$} & 0.60 & {$[0.16,2.25]$} \\
\hline Adjara & & & & & $0.36^{*}$ & {$[0.16,0.79]$} & $0.20^{* * *}$ & {$[0.09,0.42]$} \\
\hline Shida-Kartli & & & & & 0.93 & {$[0.30,2.84]$} & $0.28 *$ & {$[0.09,0.83]$} \\
\hline Kaxeti & & & & & 0.86 & {$[0.18,4.06]$} & $0.28^{*}$ & {$[0.09,0.82]$} \\
\hline Kvemo-Kartli & & & & & 0.62 & {$[0.23,1.65]$} & $0.41^{*}$ & {$[0.17,0.98]$} \\
\hline Samegrelo & & & & & 2.51 & {$[0.91,6.89]$} & 0.85 & {$[0.36,1.98]$} \\
\hline Imereti & & & & & 0.47 & {$[0.20,1.07]$} & 0.90 & {$[0.41,1.97]$} \\
\hline Samcxe-Javaxeti & & & & & 0.31 & {$[0.08,1.27]$} & 1.25 & {$[0.28,5.49]$} \\
\hline Mcxeta-Tianeti & & & & & $0.25^{*}$ & {$[0.08,0.82]$} & 0.48 & {$[0.14,1.66]$} \\
\hline McFadden's pseudo- $\mathrm{R}^{2}$ & 0.11 & & 0.10 & & 0.18 & & 0.20 & \\
\hline $\mathrm{N}$ & 814 & & 814 & & 655 & & 655 & \\
\hline
\end{tabular}

Note: $\mathrm{OR}=$ odds ration; $\mathrm{CI}=95 \%$ confidence intervals in brackets; All samples in this analysis exclude children whose parents are divorced. ${ }^{*} p<0.05,{ }^{* *} p<0.01,{ }^{* * *} p<0.001$.

of fathers and grandparents as caregivers and suggests that a kin family environment is protective of these children. As a result, this study more closely aligns with recent empirical research that describes the paradigm of care and the protective role of family members for children in transnational care (Cebotari and Mazzucato, 2016; Robila, 2012; Svintradze and Ubiria, 2007; Vanore, 2015).

The findings also speak to research on migration and divorce (Creighton et al., 2009; Mazzucato and Cebotari, 2016; Nobles, 2011) by considering whether marital discord is patterned in a way to influence children's education more negatively. We observed two findings that run counter to such an assumption. First, parental migration that involves either marital dissolution or a stable relationship appears to positively impact children's school performance in Moldova, according to self-reports. Second, the marital status of migrant parents does not have a differing effect on school performance of Georgian children in migrant and nonmigrant families. These findings are consistent with recent research on divorce, migration and children's education in other contexts (Cebotari and Mazzucato, 2016) but run counter to studies that found marital disruption to result in conflict (Constable, 2003), single parenthood (Creighton et al., 2009) and poor educational outcomes (Nobles, 2011). However, the absence of a negative relationship between marital discord and children's school performance does not necessarily indicate that the divorce discourse in the literature has always been misplaced. In the past decade, the advance in communication technologies has made transnational communication much easier and affordable. It may be that regular phone calls and online interactions with children provide divorced parents with the necessary channels to stay engaged with children and be involved in decisions concerning their lives, including those related to schooling. Indeed, auxiliary analyses of our data (not shown) reveal that married and divorced migrant parents have similar patterns of engagement with their children back home. Specifically, $97 \%$ and $86 \%$ of Moldovan and Georgian children, respectively, talk about school at least once a week with their migrant parents who are in a stable marital relationship. For divorced migrant parents, the weekly communication rate with their children is $83 \%$ in both Moldova and Georgia. In this context, the pattern of investment of divorced migrant parents appears to match the pattern of investment of migrant parents who are in a stable marital relationship. The evidence discussed here adds an important reflection: that is, divorced migrant parents stay involved in children's lives during the migration event. Future research will do well to additionally analyze specifics of parental involvement in children's education when migration and marital tensions coalesce.

The second contribution of this study is in measuring both selfand caregiver-reports when assessing school performance. Overall, there is little evidence in our findings to suggest divergent assessments by children and caregivers in Georgia, but the analysis does suggest some differing perceptions in assessments of school performance in Moldova. More specifically, the Moldovan results based on self- and caregiver-reports differ relative to parental migration and the marital status, paternal migration when mothers are caregivers, and the absence of remittances. However, 
there was no evidence to conclude that caregivers in Moldova had more negative assessments of school performance compared to child self-reports. One exception was noted when children living in non-remitting households were less likely to be assessed as performing better in school by caregivers, in contrast to selfreports. This finding provides an indication that Moldovan caregivers may view the absence of remittances as a factor that particularly disadvantages children in school. Also, children are better able to internalize the negative effects of migration by relying on social norms and support from the wider local community (Cebotari et al., 2016). Research in a number of Southeast Asian countries also revealed specific transnational family configurations relative to parental migration that may influence caregivers to evaluate children's school performance more negatively compared to children's reports (Jordan and Graham, 2012). More research is needed to understand the time-varying consistency in assessing the school performance of children based on self- and caregiver-reports.

The aforementioned findings have important policy implications. We found patterns of variation in children's education when considering different transnational family arrangements. Policy responses should cultivate more evidence-based policy discourses about migration that would account for the complexity of life of children in transnational care in a timely manner. Both countries have established technical frameworks to address the effects of migration from a policy perspective. In Moldova, children who stay at origin were specifically addressed in a national action plan, which was originally drafted for the period 2010-2011 and intended to protect children affected by migration and to ensure the observance of their rights. In Georgia, the policy response is led by the State Commission on Migration Issues (SCMI), whose main goal is to strengthen the coordination of different agencies working on migration. The agencies in both countries work on the assumption that children of migrants are worse-off than their peers in non-migrant families (Vanore, 2015). The factual basis of this assumption is not grounded in empirical data that specifically target the diversity of transnational family forms of living and how they relate with children's outcomes. Our findings show that family members' migration is not always detrimental for children. In fact, under specific transnational family configurations, children of migrants have often better or no differing school performance than children in non-migrant families. This evidence can be used by state agencies to shape a more informed policy response.

In addition, both countries will benefit from more systematic data collection and analysis, preferable in a longitudinal manner. The statistical offices in Moldova and Georgia regularly collect Household Budget Survey (HBS) data. Clusters of questions could be included into future rounds of HBS that would gather up-to-date information about migrant families and the outcomes of children in transnational care. Instead of relying on data collected years ago, the evidence collected by HBS will help reveal ongoing developments of migration and adjust the policy response in a timely manner.

This study has also limitations. Given the cross-sectional nature of the data, causal impact could not be established, and therefore, the results of this study must be considered as exploratory. The next step in this area of study awaits panel data collection. The child questionnaire in the data records only children aged 11-18. Therefore, the analysis could not explore the school performance of younger children. Within our sample, there was a rather small number of children with one or both parents abroad. It was thus not possible to further split the transnational characteristics and conduct an analysis on specifics of migration such as the gender of the parent in the context of marital dissolution, country of destination, frequency of contact, and the employment and residence status abroad. Future research should target these dimensions more in detail.

Despite these shortcomings, this study employs populationrepresentative evidence and explores in a comparative way how different transnational family configurations relate to children's school performance in Moldova and Georgia. Instead of viewing migration through simplistic lens, the empirical evidence of this study helps provide an understanding of how complex the transnational life of children is and what specific transnational forms of care matter for children's education. The current study is also a rare opportunity to look at how children and caregivers report on the outcome. It shows that at least in the case of Moldova it is important whether children or caregivers make the assessment. Future studies that employ additional transnational family configurations and use data from other geographical contexts will be helpful to advance these lines of inquire.

\section{Acknowledgement}

Financial support from EuropeAid (DCI-MIGR/210/229-604) is gratefully acknowledged.

\section{References}

Amato, P.R., Cheadle, J., 2005. The long reach of divorce: divorce and child wellBeing across three generations. J. Marriage Family 67 (1), 191-206. doi:http:// dx.doi.org/10.1111/j.0022-2445.2005.00014.x.

Antman, F.M., 2011. International migration and gender discrimination among children left behind. Am. Econ. Rev. 101 (3), 645-649. doi:http://dx.doi.org/ 10.1257/aer:101.3.645.

Antman, F.M. 2012. Gender, educational attainment and the impact of parental migration on children left behind. J. Popul. Econ. 25 (4), 1187-1214 10.1007\% 2Fs00148-012-0423-y.

Battistella, G., Conaco, C., 1998. The impact of labour migration on the children left behind: a study of elementary school children in the Philippines. J. Social Issues Southeast Asia 13 (2), 220-241. doi:http://dx.doi.org/10.1355/sj13-2c.

Bennett, R., Clifford, D., Falkingham, J., 2013. Household members' migration and the education of children 'left behind': empirical findings from Tajikistan and reflections for research practice. Popul. Space Place 19 (1), 1-14. doi:http://dx. doi.org/10.1002/psp.1698.

Bredl, S., 2010. Migration, remittances and educational outcomes: the case of Haiti. Int. J. Educ. Dev. 31 (2), 162-168. doi:http://dx.doi.org/10.1016/j. ijedudev.2010.02.003.

Caarls, K. (2015). Living apart together across borders: How Ghanaian couples form, transform, or disolve in the context of international migration. (PhD thesis), Maastricht University, Maastricht, the Netherlands. Retrieved from http:// digitalarchive.maastrichtuniversity.nl/fedora/get/guid:91246c40-32dc-441288c2-6fd79251f714/ASSET1.

Cebotari, V., Mazzucato, V., 2016. Educational performance of children of migrant parents in Ghana, Nigeria and Angola. J. Ethnic Migr. Stud. 42 (5), 834-856. doi: http://dx.doi.org/10.1080/1369183x.2015.1125777.

Cebotari, V., Mazzucato, V., Siegel, M., 2016. Gendered perceptions of migration among Ghanaian children in transnational care. Child Indic. Res. doi:http://dx doi.org/10.1007/s12187-016-9407-x.

Constable, N., 2003. A transnational perspective on divorce and marriage: filipina wives and workers. Identities: Glob. Stud. Cult. Power 10 (2), 163-180. doi: http://dx.doi.org/10.1080/10702890304328.

Corak, M., 2001. Death and divorce: the long-term consequences of parental loss on adolescents. J. Labor Econ. 19 (3), 682-715.

Cortes, P., 2015. The feminization of international migration and its effects on the children left behind: evidence from the Philippines. World Dev. 65, 62-78. doi: http://dx.doi.org/10.1016/j.worlddev.2013.10.021January.

Creighton, M., Park, H., Teruel, G., 2009. The role of migration and single motherhood in upper secondary education in Mexico. J. Marriage Family 71 (5), 1325-1339. doi:http://dx.doi.org/10.1111/j.1741-3737.2009.00671.x.

Dreby, J., 2010. Divided by Borders: Mexican Migrants and Their Children. Berkeley: University of California Press.

Dustmann, C., 2003. Children and return migration. J. Popul. Econ. 16 (4), 815-830. doi:http://dx.doi.org/10.1007/s00148-003-0161-2.

Edwards, A., Ureta, M., 2003. International migration, remittances, and schooling: evidence from El Salvador. J. Dev. Econ. 72 (2), 429-461. doi:http://dx.doi.org/ 10.1016/s0304-3878(03)00115-9.

Gerber, T., Torosyan, K., 2013. Remittances in the Republic of Georgia: correlates, economic impact, and social capital formation. Demography 50 (4), 1279-1301. doi:http://dx.doi.org/10.1007/s13524-013-0195-3.

Giannelli, G., \& Mangiavacchi, L. (2010). Children's schooling and parental migration: empirical evidence on the "left behind" generation in Albania. IZA Discussion Papers. Institute for the Study of Labor (IZA). Bonn, Germany. 
Grigorian, D.A., Melkonyan, T.A., 2011. Destined to receive: the impact of remittances on household dcisions in Armenia. Rev. Dev. Econ. 15 (1), 139-153. doi:http://dx.doi.org/10.1111/j. 1467-9361.2010.00598. x.

Hu, F., 2012. Migration, remittances, and children's high school attendance: the case of rural China. Int. J. Educ. Dev. 32 (2), 401-411. doi:http://dx.doi.org/10.1016/j. ijedudev.2011.08.001.

Jordan, L.P., Graham, E., 2012. Resilience and well-being among children of migran parents in South-East Asia. Child Dev. 83 (5), 1672-1688. doi:http://dx.doi.org 10.1111/j.1467-8624.2012.01810.x.

Kandel, W., Kao, G., 2001. The impact of temporary labor migration on Mexican children's educational aspirations and performance. Int. Migr. Revi. 35 (4), 1205-1231.

Kroeger, A., Anderson, K.H., 2014. Remittances and the human capital of children: new evidence from Kyrgyzstan during revolution and financial crisis, 20052009. J. Comp. Econ. 42 (3), 770-785. doi:http://dx.doi.org/10.1016/j. jce.2013.06.001.

Labadze, L., \& Tukhashvili, M. (2013). Costs and benefits of labour mobility between the EU and the eastern partnership partner countries. Country report Georgia (pp. 54). Warsaw, Poland: Center for Social and Economic Research. Retrieved from http://www.case-research.eu/en/node/58255.

Lu, Y., 2014. Parental migration and education of left-behind children: a comparison of two settings. J. Marriage Family 76 (5), 1082-1098. doi:http://dx.doi.org/ $10.1111 /$ jomf.12139.

Mazzucato, V., Cebotari, V., 2016. Psychological well-being of Ghanaian children in transnational families. Popul. Space Place doi:http://dx.doi.org/10.1002/ psp.2004.

Mazzucato, V., Cebotari, V., Veale, A., White, A., Grassi, M., Vivet, J., 2015. International Parental Migration and the Psychological Well-being of Children in Ghana, Nigeria, and Angola. Soc. Sci. Med. 132 (May), 215-224. doi:http://dx. doi.org/10.1016/j.socscimed.2014.10.058.

McKenzie, D., Rapoport, H., 2011. Can migration reduce educational attainment? Evidence from Mexico. J. Popul. Econ. 24 (4), 1331-1358. doi:http://dx.doi.org/ 10.1007/s00148-010-0316-X.

McLanahan, S.S., Sandefur, G., 1994. Growing up with a Single Parent: What Hurts What Helps. Harvard University Press, Cambridge, MA.
Nobles, J., 2011. Parenting from abroad: migration, nonresident father involvement, and children's education in Mexico. J. Marriage Family 73 (4), 729-746. doi: http://dx.doi.org/10.1111/j.1741-3737.2011.00842.x.

Parreñas, R.S., 2005. Children of Global Migration: Transnational Families and Gendered Woes. Stanford University Press, Stanford, CA.

Robila, M., 2012. The impact of migration on children's psychological and academic functioning in the Republic of Moldova. Int. Migr. 52 (3), 221-235. doi:http://dx. doi.org/10.1111/imig.12029.

Smith, A., Lalonde, R.N., Johnson, S., 2004. Serial migration and its implications for the parent-child relationship: a retrospective analysis of the experiences of the children of Caribbean immigrants. Cultur. Divers. Ethnic Minor. Psychol. 10 (2), 107-122. doi:http://dx.doi.org/10.1037/1099-9809.10.2.107.

Stark, O., Helmenstein, C., Prskawetz, A., 1997. A brain gain with a brain drain. Econ. Lett. 55 (2), 227-234. doi:http://dx.doi.org/10.1016/S0165-1765(97)00085-2.

Svintradze, I., \& Ubiria, G. (2007). How poverty separates families: Impact of international labour migration on families and children in Georgia (pp. 24). Tbilisi, Georgia: Caucasus Research Resource Centre (CRRC). Retrieved from http://www.crrc.ge/uploads/files/publications/archive/ Ia_Svintradze_and_Grigol_Ubiria_-_Eng.pdf.

UNDP. (2013). Human Development Index and its components. New York: United Nations Development Programme. Retrieved from http://hdr.undp.org/en/ content/table-1-human-development-index-and-its-components\#a.

UNICEF. (2016). Assessment and recommendations to improve the resilience of the social protection system for a timely and flexible response to the needs of all vulnerable children and families facing shocks, disasters, and crises in Moldova. UNICEF Moldova Office. Retrieved from http://www.merit.unu.edu/ publications/uploads/1472459213.pdf.

Vanore, M. (2015). Family-member migration and the psychosocial health outcomes of children in Moldova and Georgia. (PhD degree), Maastricht University, Maastricht, the Netherlands. Retrieved from http://digitalarchive. maastrichtuniversity.nl/fedora/get/guid:67fa2a26-bac5-49ff-adbecef3c0d0b74d/ASSET1.

World Bank. (2011). Migration and remittances fact book 2011. Washington D.C. doi: 10.1596/978-0-8213-8218-9. 